\begin{tabular}{|c|c|c|}
\hline$=$ & Publisher: Faculty of Agronomy Čačak & 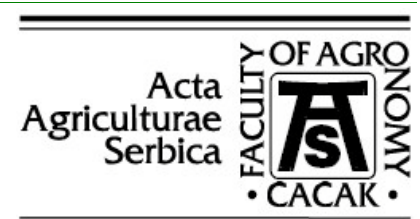 \\
\hline
\end{tabular}

\title{
Foliar fertilization with phosphorus and potassium in red clover seed production on an acidic soil
}

\author{
Dalibor Tomić1 ${ }^{*}$, Vladeta Stevović ${ }^{1}$, Aleksandar Simić ${ }^{2}$, Dragan Đurović ${ }^{1}$, Mirjana \\ Radovanović ${ }^{1}$, Milomirka Madić, Jasmina Knežević ${ }^{3}$
}

1 University of Kragujevac, Faculty of Agronomy, Čačak, Republic of Serbia

2 University of Belgrade, Faculty of Agriculture, Belgrade, Republic of Serbia

3 Univerzity of Priština, Faculty of Agriculture, Lešak, Republic of Serbia

*Corresponding author: dalibort@kg.ac.rs

Received 14 April 2020; Accepted 29 May 2020

\begin{abstract}
A B S T R A C T
A field trial with four red clover cultivars ('K-39', 'K-17', 'Una' and 'Viola') was conducted on a leached vertisol acid in reaction ( $p H_{H 2 O}$ 4.8) to assess the effect of foliar treatment with phosphorus and potassium on seed yield and seed yield components. A single foliar application of phosphorus and potassium $\left(P_{52} K_{34}\right)$ was made at the intensive growth stage during the second growth in the second year of cultivation. Seed yield and seed yield components were analyzed from the second growth in the second year of the experiment. Foliar treatment with phosphorus and potassium had a significant positive effect on seed yield and yield components in some red clover cultivars in some years. The most positive effect was recorded in ' $\mathrm{K}-17$ ' and 'Viola'. The different effects of foliar-applied mineral fertilizers on the tested cultivars were the result of their phenotypic differences. Foliar treatment gave the best performance in 2011, when the climatic conditions were the most favorable for red clover growth and development. In general, the seed yield of

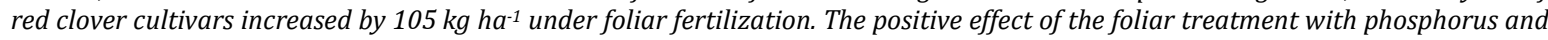
potassium was attributed to the need for these elements in many plant processes. The results showed that the foliar application of mineral fertilizers in red clover seed production on acid soils can be an acceptable practice under conditions favoring high yields.
\end{abstract}

Keywords: phosphorus, potassium, foliar spray, red clover, seed yield.

\section{И 3 В О д}

Пољски оглед са четири сорте црвене дателине K-39, K-17, Уна и Виола је постављен на земљишту типа лесивирана смоница, киселе реакције $\left(\mathrm{pH}_{\mathrm{H} 20}\right.$ 4.8) са циљем да се одреди утицај фолијарних третмана фосфором и калијумом на принос и компоненте приноса семена. Фолијарна примена фосфора и калијума $\left(\mathrm{P}_{52} \mathrm{~K}_{34}\right)$ је извршена у фази интензивног раста током другог пораста у другој години производње. У периоду од цветања до жетве су анализиране најважније компоненте приноса и принос семена. Фолијарна примена фосфора и калијума је имала значајан позитиван утицај на принос семена и компоненте приноса семена појединих сорти црвене детелине у појединим годинама. Најпозитивнији утицај је заблежен код сорти K-37 и виола. Различит утицај фолијарно примењених минералних хранива на сорте је резултат њихових фенотипских разлика. Фолијарни третман минералним хранивима је дао најбоље резултате у 2011. години, када су климатски услови за успевање црвене детелине били најповољнији. Генерално посматрано, принос семена сорти црвене детелине је повећан под утицајем фолијарне прихране за $105 \mathrm{~kg} \mathrm{ha}^{-1}$. Позитиван утицај фолијарног третмана фосфором и калијумом се приписује неопходности ових елемената у многим процесима у биљци. Резултати указују да фолијарна примена минералних хранива у семенској производњи црвене детелине на киселим земљиштима може бити прихватљива мера у условима када су обезбеђени и остали услови за постизање високих приноса.

Кључне речи: ирвена детелина, фосфор, фолијарно ђубрење, калијум, принос семена.

\section{Introduction}

An obstacle to to the normal growth and development of plants of the family Fabaceae is a lack of available phosphorus (Gitari and Mureithi, 2003; Okalebo et al., 2009) and potassium (Abel et al., 2002; Mathur et al., 2006) in the soil.

In Southeast Europe, red clover (Trifolium pratense L.) seed crops are commonly established on acidic soils, in which certain macro- and micronutrients are less available to plants. In such soils, phosphorus can be dominantly adsorbed onto aluminum and iron oxides and calcium hydroxides. Also, the slow diffusion of phosphorus in the soil limits its the rhizosphere (Raghothama and Karthikeyan, 2005). Phosphorus fertilizers are mobile in the form of orthophosphates, but $80 \%$ of the amount of phosphorus fertilizers applied is rapidly immobilized into other forms. This mostly results in their accumulation in the soil in forms unavailable to plants (the so-called "unavailable" phosphorus). Fixed phosphorus is gradually lost from the soil by leaching or through surface waters. This leads to the pollution of the environment, particularly water (Turner et al., 2002; Jianbo et al., 2011), especially in European and American areas intensively fertilized with phosphorus over long periods of time (Sharpley et al., 2005). 
Potassium is the most widely distributed inorganic cation in plant cells (Dreyer and Uozumi, 2011), and is required by plants in large amounts (Xu et al., 2011). Its concentration is 3-4 times greater in plants than in the soil; therefore, plants need energy for its uptake (Dreyer and Uozumi, 2011). Potassium reserves in the soil are on average mostly large, but most of the total potassium is unavailable to plants (Zörb et al., 2014). The amount of available potassium in the soil ranges from about 2 to $10 \%$. The remaining $90-98 \%$ of total potassium is in the form of insoluble rocks and silicate minerals (Römheld and Kirkby, 2010; Parmar and Sindhu, 2013). The availability of potassium to plants is highly variable due to complex dynamic processes, which are strongly affected by the root-soil interaction (Ashley et al., 2006; Lester et al., 2010). Drought is a potential constraint to the uptake of potassium, and can cause deficiency symptoms in plants. On clayey soils exhibiting high potassium fixation capacity, fertilization with this nutrient has a small effect on plants as the large part of potassium is rapidly bound to clay particles (Brady and Weil, 1999). In the near future, an increase in potassium fertilizer price is expected (Zörb et al., 2014). Therefore, focus is being placed on finding alternative ways to supply potassium to plants (Manning, 2009; White and Greenwood, 2013). One alternative is foliar fertilization. Foliar treatment is used for the rapid elimination of nutrient deficiencies in plants, and is, therefore, more effective than soil fertilization (Silberbush, 2002). Foliar feeding of mineral nutrients is particularly important under unfavorable soil conditions.

A number of studies have indicated that foliar treatment with phosphorus (Noack et al., 2011) and potassium (Lester et al., 2007; Lester et al., 2010; Zörb et al., 2014) can successfully remove their deficiencies in various plant species, while protecting the environment.

The objective of the present study was to analyze the effect of foliar phosphorus and potassium treatment on seed yield and yield components of red clover cultivars grown an acidic soil.

\section{Materials and method}

\section{Soil properties}

A field trial was conducted at the Veterinary Extension Service in Čačak $\left(43^{\circ} 54^{\prime} 39.06^{\prime \prime} \mathrm{N}\right.$, $20^{\circ} 19^{\prime} 10.21 "$ E, $243 \mathrm{~m}$ a.s.l.) in 2009-2012. The experiment was established on a leached vertisol $\mathrm{pH}$ 4.8 ), which contained $3.18 \%$ organic matter, $0 \% \mathrm{CaCO}_{3}$, $22.08 \mathrm{mg}$ extractable $\mathrm{P} 100 \mathrm{~g}^{-1}$ soil and $30.0 \mathrm{mg} \mathrm{K} 100$ $\mathrm{g}^{-1}$ soil. Prior to seeding and in autumn, $45 \mathrm{~kg} \mathrm{ha}^{-1} \mathrm{~N}, 45$ $\mathrm{kg} \mathrm{ha}^{-1} \mathrm{P}_{2} \mathrm{O}_{5}$, and $45 \mathrm{~kg} \mathrm{ha}^{-1} \mathrm{~K}_{2} \mathrm{O}$ were incorporated into the soil.

\section{Weather conditions}

Data on mean monthly temperatures and rainfall were recorded throughout the experiment at a weather station located near the red clover stand. The mean annual air temperature in 2010, 2011, 2012 and for the long-term period (1992-2002) was $12.6^{\circ} \mathrm{C}, 12.4{ }^{\circ} \mathrm{C}$, $13.1{ }^{\circ} \mathrm{C}$ and $12.0^{\circ} \mathrm{C}$, respectively. Monthly rainfall (Figure 1.) showed large variations during the growing season (April-September).

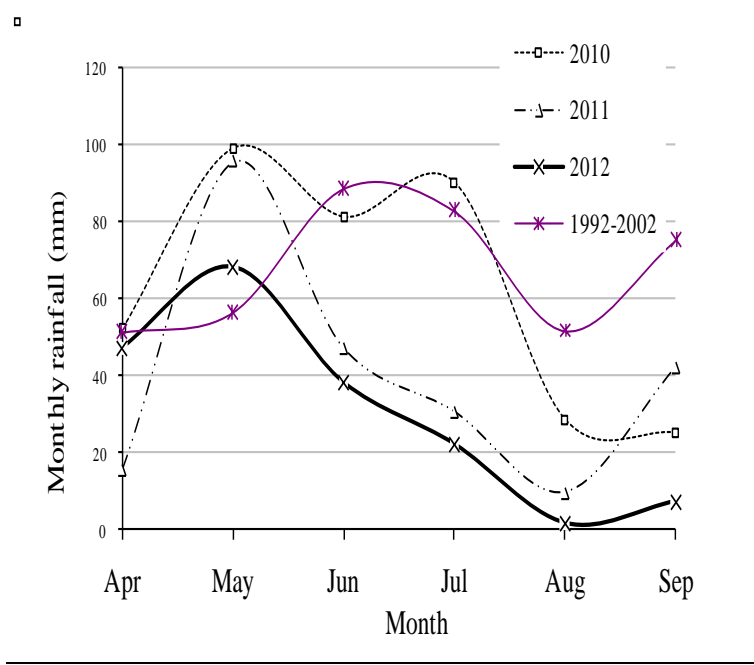

Figure 1. Monthly rainfall distribution for experimental years and the 10-year (1992-2002) average

\section{Experimental design}

The experiment involving four red clover cultivars and two treatments (control, foliar application of phosphorus and potassium, PK) was laid out in a randomized block design with four replications and with a plot size of $5 \times 1 \mathrm{~m}$. Red clover cultivars 'K-17', 'K-39' (Institute for Forage Crops, Kruševac, Serbia), 'Una' (Institute of Field and Vegetable Crops, Novi Sad, Serbia) and 'Viola' (a Polish variety) were sown at an inter-row spacing of $20 \mathrm{~cm}$, using $18 \mathrm{~kg}$ seeds ha-1. Seeding was performed on 3 April 2009, 27 March 2010 and 26 March 2011. The crop received a single foliar application of PK (as $\mathrm{P}_{52} \mathrm{~K}_{34}$ ), at a concentration of $1 \%$ and a water rate of $1000 \mathrm{~L} \mathrm{ha}^{-1}$, at the intensive growth stage during the second growth in the second year of cultivation. Mechanical weed control was performed twice in the year of sowing. No irrigation was employed.

\section{Measurements}

Seed yield and yield components were determined from the second growth in the second year of cultivation (in 2010, 2011 and 2012). The following yield components were determined in the field: number of stems $\mathrm{m}^{-2}$ and number of inflorescences $\mathrm{m}^{-2}$ (by counting within an area of $0.2 \mathrm{~m}^{2}$ per plot) and number of inflorescences per stem (by counting in a sample of ten randomly selected middle-row stems per plot) (Oliva et al., 1994). Laboratory work included determination of the number of flowers per inflorescence and number of seeds per inflorescence (in a sample of ten inflorescences per plot), and thousand seed weight (based on the weight of $5 \times 100$ seeds extracted from the same sample and pods). Fertility was calculated and expressed as a percentage of the total number of flowers and seeds per inflorescence. The actual seed yield was determined using yield components (number of inflorescences per unit area, number of seeds per inflorescence, thousand seed weight) and converted to seed yield in $\mathrm{kg} \mathrm{ha}^{-1}$ (Oliva et al., 1994). 
Root nodule development and the chlorophyll content of red clover leaves were determined at flowering in the second cut during the second crop year. Five plants were sampled per treatment and per cultivar for the determination of the total number of nodules up to a depth of $20 \mathrm{~cm}$. The analysis of the chlorophyll content was made spectrophotometrically by the method of Cvijović and Aćamović (2000).

The results obtained were subjected to a mixeddesign analysis of variance model (year as a random effect, cultivars and foliar fertilization as fixed effects) using SPSS (SPSS 1995). Differences between means were tested by LSD test. To satisfy the requirement of normality, the data for number of stems $\mathrm{m}^{-2}$, number of inflorescences $\mathrm{m}^{-2}$, number of flowers per inflorescence and number of seeds per inflorescence were transformed prior to the analysis of variance using the form $\sqrt{\mathrm{x}}$ or $\sqrt{\mathrm{x}}+1$ for number of inflorescences per stem.

\section{Results}

The foliar application of phosphorus and potassium significantly increased the number of stems only in 2011 (year $\mathrm{x}$ foliar treatment interaction) (Table 1.). The positive effect of foliar treatment on the number of stems was recorded only in the ' $\mathrm{K}-39$ ' cultivar (cultivar $\mathrm{x}$ foliar treatment interaction). Due to the effect of the foliar treatment on the number of stems and number of inflorescences per stem, the foliar treatment was effective in significantly increasing the number of inflorescences $\mathrm{m}^{-2}$ in all cultivars in 2011 (year $\mathrm{x}$ foliar treatment interaction).
Foliar phosphorus and potassium also led to a significantly increased number of flowers per inflorescence in 2010 and 2011. A positive effect of foliar treatment on the number of flowers per inflorescence was observed in 'K-17' and 'Viola' cvs. whereas a positive effect of the treatment on flower fertility was observed only in 'K-17'. Identically to the effect on the number of flowers per inflorescence, the foliar treatment with phosphorus and potassium significantly promoted the number of seeds per inflorescence in 'K-17' and 'Viola' and in the 2011.

The positive effect of the foliar application of phosphorus and potassium in increasing the number of inflorescences $\mathrm{m}^{-2}$ and number of seeds per inflorescence made a significant contribution to seed yield especially in 2011. A significant increase in number of inflorescences $\mathrm{m}^{-2}$ and number of seeds per inflorescence under the influence of foliar treatment was observed in cultivars 'K-17' and 'Viola'.

Regardless of foliar treatment, 'K-17' had a significantly lower chlorophyll "a" content compared to the other cultivars, whereas chlorophyll " $b$ " content was significantly greater in 'Una' than in 'K-17' (Table 2.). As the result of its lower chlorophyll "a" content, 'K17' had a lower total chlorophyll content. A significantly higher number of root nodules in the control was found in 'K-17' compared to 'Viola'. The foliar application of phosphorus and potassium did not have a significant effect on leaf chlorophyll content and nodule formation in red clover cultivars. 
Table 1

Seed yield components and seed yield of red clover cultivars as dependent upon foliar treatment with phosphorus and potassium

\begin{tabular}{|c|c|c|c|c|c|c|c|c|c|}
\hline & & SM & IS & IM & FI & SI & $\mathrm{F}$ & TSW & SY \\
\hline \multirow{2}{*}{$\begin{array}{l}\text { Foliar } \\
\text { treatment }(\mathrm{T})\end{array}$} & $\varnothing$ & $311.5 b$ & 2.32 & $713 \mathrm{~b}$ & $73.6 \mathrm{~b}$ & $31.3 \mathrm{~b}$ & 41.2 & 1.47 & $297 b$ \\
\hline & $\mathrm{PK}$ & $330.9 a$ & 2.36 & $772 \mathrm{a}$ & $78.4 \mathrm{a}$ & $35.9 \mathrm{a}$ & 43.7 & 1.27 & $402 a$ \\
\hline \multicolumn{10}{|l|}{ Year (Y) } \\
\hline \multirow[t]{2}{*}{2010} & $\varnothing$ & $330.3 b$ & 1.64 & $550 \mathrm{~d}$ & $61.1 \mathrm{~d}$ & $30.5 c$ & 48.8 & 1.35 & $220 \mathrm{~cd}$ \\
\hline & PK & $346.2 b$ & 1.83 & $609 \mathrm{~cd}$ & $69.1 c$ & $33.0 \mathrm{c}$ & 47.9 & 1.30 & $271 c$ \\
\hline \multirow[t]{2}{*}{2011} & $\varnothing$ & $333.1 b$ & 2.39 & $799 b$ & $92.8 b$ & $50.2 \mathrm{~b}$ & 54.1 & 1.89 & $549 b$ \\
\hline & PK & $382.8 \mathrm{a}$ & 2.58 & $989 a$ & $100.0 \mathrm{a}$ & $60.3 a$ & 60.1 & 1.37 & $820 a$ \\
\hline \multirow[t]{2}{*}{2012} & $\varnothing$ & $270.9 c$ & 2.93 & $790 \mathrm{~b}$ & $67.0 \mathrm{~cd}$ & $13.3 \mathrm{~d}$ & 20.7 & 1.16 & $123 d$ \\
\hline & $\mathrm{PK}$ & $263.8 c$ & 2.67 & $718 \mathrm{bc}$ & $66.2 \mathrm{~cd}$ & $14.3 \mathrm{~d}$ & 23.2 & 1.14 & $115 \mathrm{~d}$ \\
\hline \multicolumn{10}{|l|}{ Cultivar (C) } \\
\hline \multirow[t]{2}{*}{ ‘К-39’ } & $\varnothing$ & $310.0 \mathrm{bc}$ & 2.45 & 746 & $78.2 \mathrm{~b}$ & $32.2 \mathrm{bc}$ & $40.0 \mathrm{abc}$ & 1.34 & $321 b$ \\
\hline & PK & $345.6 \mathrm{a}$ & 2.37 & 830 & $76.7 \mathrm{~b}$ & $33.1 b c$ & $42.1 \mathrm{abc}$ & 1.26 & $414 \mathrm{ab}$ \\
\hline \multirow[t]{2}{*}{ ‘К-17’ } & $\varnothing$ & $317.1 \mathrm{bc}$ & 2.33 & 736 & $78.0 \mathrm{~b}$ & $30.5 \mathrm{~cd}$ & $37.0 \mathrm{c}$ & 1.34 & $318 b$ \\
\hline & PK & $331.7 \mathrm{ab}$ & 2.51 & 817 & 87.1a & $42.7 \mathrm{a}$ & $46.5 \mathrm{ab}$ & 1.38 & $521 a$ \\
\hline \multirow[t]{2}{*}{ 'Una' } & $\varnothing$ & $330.0 \mathrm{ab}$ & 2.42 & 784 & $76.2 \mathrm{~b}$ & $37.5 \mathrm{ab}$ & $48.1 \mathrm{a}$ & 1.29 & $384 b$ \\
\hline & PK & $331.7 \mathrm{ab}$ & 2.38 & 795 & $77.3 \mathrm{~b}$ & $32.2 \mathrm{bc}$ & 40.3abc & 1.27 & $353 b$ \\
\hline \multirow[t]{2}{*}{ 'Viola' } & $\varnothing$ & $288.8 c$ & 2.08 & 587 & $62.0 \mathrm{c}$ & $25.1 \mathrm{~d}$ & $39.7 b c$ & 1.91 & $166 c$ \\
\hline & $\mathrm{PK}$ & $305.0 \mathrm{bc}$ & 2.17 & 647 & $72.6 \mathrm{~b}$ & $35.0 \mathrm{bc}$ & $46 a b$ & 1.17 & $321 b$ \\
\hline $\mathrm{T}$ & & $*$ & ns & $*$ & $*$ & $*$ & ns & ns & $*$ \\
\hline $\mathrm{YxT}$ & & $*$ & ns & $*$ & $*$ & $*$ & ns & ns & $*$ \\
\hline $\mathrm{C} \times \mathrm{T}$ & & ns & ns & ns & ns & $*$ & $*$ & ns & $*$ \\
\hline $\mathrm{T} \times \mathrm{Y} \times \mathrm{C}$ & & ns & ns & ns & ns & ns & ns & ns & ns \\
\hline
\end{tabular}

SM - stems $\mathrm{m}^{-2}$, IS - inflorescences per stem, IM - inflorescences $\mathrm{m}^{-2}$, FI - flowers per inflorescence, SI - seeds per inflorescence, F fertility (\%), TSW - thousand seed weight (g), SY - seed yield $\left(\mathrm{kg} \mathrm{ha}^{-1}\right)$.

Values followed by different small letters within columns are significantly different $(\mathrm{P}<0.05)$ according to the LSD test; "Fhiser's test significant at $\mathrm{P} \leq 0.05$; ns - non-significant

Table 2

Chlorophyll "a", chlorophyll "b" and total chlorophyll "a+b" contents in leaves of red clover cultivars at flowering and number of root nodules as affected by foliar treatment

\begin{tabular}{cccccc}
\hline & & $\begin{array}{c}\text { Chlorophyll a } \\
\left(\mathrm{mg} \mathrm{kg}^{-1}\right)\end{array}$ & $\begin{array}{c}\text { Chlorophyll b } \\
\left(\mathrm{mg} \mathrm{kg}^{-1}\right)\end{array}$ & $\begin{array}{c}\text { Chlorophyll a+b } \\
\left(\mathrm{mg} \mathrm{kg}^{-1}\right)\end{array}$ & $\begin{array}{c}\text { Number of root } \\
\text { nodules }\end{array}$ \\
\hline \multirow{2}{*}{ Cultivar } & 'K-39' & $2342 \mathrm{a}$ & $175.2 \mathrm{ab}$ & $2517 \mathrm{a}$ & $48.4 \mathrm{ab}$ \\
& 'K-17' & $1586 \mathrm{~b}$ & $221.9 \mathrm{~b}$ & $1808 \mathrm{~b}$ & $58.4 \mathrm{a}$ \\
& 'Una' & $1789 \mathrm{a}$ & $247.3 \mathrm{a}$ & $3036 \mathrm{a}$ & $46.8 \mathrm{ab}$ \\
& 'Viola' & $2503 \mathrm{a}$ & $247.9 \mathrm{ab}$ & $2751 \mathrm{a}$ & $37.8 \mathrm{~b}$ \\
\hline \multirow{2}{*}{ Treatment } & $\varnothing$ & $2319 \mathrm{a}$ & $211.4 \mathrm{a}$ & $2531 \mathrm{a}$ & $30.4 \mathrm{a}$ \\
& $\mathrm{PK}$ & $2481 \mathrm{a}$ & $263.8 \mathrm{a}$ & $2745 \mathrm{a}$ & $42.5 \mathrm{a}$ \\
\hline
\end{tabular}

Values followed by different small letters within cultivar and treatment columns are significantly different $(\mathrm{P}<0.05)$ according to the Kruskal-Wallis test

\section{Discussion}

The foliar spray of phosphorus and potassium in this experiment had a significant positive effect on the number of stems in 'K-39' and number of inflorescences $\mathrm{m}^{-2}$ in all cultivars in 2011. An adequate supply of phosphorus to plants is important for the normal growth and development of legumes (Gitari and Mureithi, 2003; Okalebo et al., 2009). Hellsten and Huss-Daness (2000) reported a positive effect of phosphorus application in red clover on the number of nodules per plant, dry matter content in the nodules and specific nitrogenase activity. However, the foliar treatment with phosphorus and potassium in the present experiment was not significantly effective in increasing the number of root nodules in red clover cultivars. This indicates that increased root nodule formation is not the reason behind the positive effect on the number of stems and number of inflorescences $\mathrm{m}^{-2}$. In this experiment, a possible reason for the absence of plant response to foliar phosphorus and potassium in terms of root nodule development is late treatment (a single foliar application, at the intensive growth stage; number of root nodules determined at flowering).

In general, the positive effect of the foliar treatment with phosphorus and potassium on vegetative growth can be attributed to their essential 
role in a number of processes in the plant. Phosphorus is a component of biologically important molecules, such as nucleic acid, phospholipids, macromolecules and physiologically active compounds in the plant and many sugar phosphate intermediaries in respiration and photosynthesis (Jianbo et al., 2011; Veneklaas et al., 2012). This role makes phosphorus very important in major biological processes, including photosynthesis, respiration and membrane transport, as well as in the metabolism of various compounds. Potassium is also required for normal life processes such as the activation of numerous enzymes (White and Karley, 2010), uptake of micro- and macronutrients (Tiwari et al., 2001), protein metabolism (Sawan et al., 2009), maintenance of cell membrane permeability (Singh, 2000), and maintenance of turgor pressure, stomatal aperture and water balance in plants (Römheld and Kirkby, 2010; Dreyer and Uozumi, 2011).

Positive effects of phosphorus and potassium on photosynthesis and photorespiration in different plant species were reported in a range of studies (Pettigrew, 2008; Sawan et al., 2009; Richardson, 2009). However, as stressed by Zörb et al. (2014), previous research has indicated inconsistency in the effect of potassium on photosynthesis in different plant species, as also confirmed by the present results. In this experiment, foliar phosphorus and potassium treatment did not lead to a significant change in chlorophyll content in red clover leaf compared to the control.

In the present experiment, foliar applied phosphorus and potassium had a significant positive effect on the number of flowers per inflorescence in 2010 and 2011 and number of seeds per inflorescence in 2011, particularly in 'K-17' and 'Viola'. Similar results in legumes were reported elsewhere. In soybean, the number of seeds per plant and seed yield were increased by potassium fertilization (Tiwari et al., 2001). Potassium deficiency caused early flowering in alfalfa, which was less abundant and non-uniform (Bahaeldeen et al., 2009). The optimum supply of soybean with phosphorus resulted in a significant increase in the number of branches per plant, thousand seed weight, number of pods per plant, number of seeds per pod and seed yield (Xiang et al., 2012; Agraw, 2012).

The foliar spray of phosphorus and potassium in the present experiment increased the seed yield of red clover. As the effect of the foliar phosphorus and potassium treatment on yield components was highest in 2011, the greatest effectiveness in improving seed yield was recorded in the same year. The positive effect of phosphorus and potassium on seed yield in legumes has also been reported elsewhere. Muir et al. (2001) found a significant increase in the seed yield of toothed bur clover (Medicago polymorpha L.) resulting from the increased number of pods per plant after phosphorus fertilization. Lewis and Hawthorne (1996) obtained a $20-30 \%$ increase in the seed yield of broad bean (Vicia faba) after phosphorus treatment. In cluster bean (Cyamopsis tetragonoloba Taub.), Burman et al. (2004) determined a significant increase in plant growth and seed yield under an adequate phosphorus supply.

Furthermore, a number of studies have shown that yield increases in legumes after potassium treatment are primarily due to the positive effect of potassium on seed yield components (Singh et al., 1999; Tiwari et al., 2001; Xiang et al., 2012). Foliar applied potassium increased soybean yield (Haq and Mallarino, 2005; Nelson et al., 2005). Potassium deficiency caused a decrease in the transport of photosynthetic assimilates from source tissues through the phloem to the other parts of the plant (Pettigrew, 2008). This led to sugar accumulation in the leaf tissue, reduced yields and decreased crop quality (Pettigrew, 2008; Zörb et al., 2014). An adequate potassium supply had a stimulating effect on seed yield in alfalfa (Grewal and Williams, 2002). However, Bahaeldeen et al. (2009) found no effect of soil application of potassium on either seed yield components or total seed yield in alfalfa, which was in agreement with the findings of Abusuwar et al, (2004). Also, the results of some other studies have confirmed the fact that soil applied fertilizers can be absorbed by the soil complex without any effect on the plant itself (Yoneyama et al., 2012; Parmar and Sindhu, 2013; Zörb et al., 2014). Therefore, a number of experiments have shown that foliar applied phosphorus and potassium can successfully remove their deficiencies in numerous crops (Lester et al., 2007; Lester et al., 2010; Zörb et al., 2014), as also indicated by the present results on red clover.

The greatest effect of foliar phosphorus and potassium treatment on yield components and, hence, seed yield was recorded in 2011, when seed yield was the highest. Due to the smaller number of seeds set per unit area as induced by unfavorable weather in 2010 and 2012, phosphorus and potassium were not constraints to high yields. Hence, the foliar treatment with these nutrients had no effect on seed yield. A positive effect of foliar applied phosphorus and potassium on the number of flowers per inflorescence was determined in 2010, when rainfall amounts were the highest. As observed by Burman et al. (2004), soil moisture conditions can largely affect the phosphorus supply of cluster bean plants (Cyamopsis tetragonoloba Taub.).

Red clover cultivars grown in dense stands differed significantly in their response to foliar phosphorus and potassium treatment as regards yield components and seed yield. The differences were primarily the result of different morphologies of plant organs, particularly the root. Similar findings were reported for some other legumes. The genotypic differences in potassium nutrition in alfalfa can be associated with the better transport of potassium to functional leaves in some genotypes during late growth stages (James et al., 1995). Soybean cultivars and genotypes exhibit differences in total potassium uptake due to differences in cultivar traits, such as root morphology, root hairs, root exudates, potassium uptake kinetics and potassium movement through the plant (White, 2013). Accordingly, it can be assumed that, in this experiment, the cultivars which were more effective in uptaking phosphorus and potassium through the soil showed a lower rate of response to the foliar treatment with these nutrients.

\section{Conclusion}

The foliar application of phosphorus and potassium had a significant positive effect on the number of stems, number of inflorescences $\mathrm{m}^{2}$, number of flowers per inflorescence, number of seeds per inflorescence and seed yield of some red clover cultivars under defined conditions. The different effects of foliar applied mineral nutrients on the tested cultivars were induced by their phenotypic differences. The most favorable weather conditions (air 
temperature and the amount and distribution of rainfall) for red clover seed production and, hence, the highest seed yield, were recorded in 2011. The obtainment of high seed yields required increased amounts of readily available phosphorus and potassium, and therefore the foliar treatment with these nutrients gave the best results. Root nodule formation was not significantly increased by foliar applied phosphorus and potassium. The positive effect of foliar phosphorus and potassium treatment is attributed to the need for these nutrients in a range of processes in the plant, such as respiration, membrane transport, metabolism of various compounds, cell division, activation of numerous enzymes, meristem tissue development, turgor pressure maintenance, uptake of micro- and macronutrients, etc. The results indicate that the foliar application of mineral nutrients in red clover seed production on acidic soils can be an acceptable practice under conditions favoring high yields.

\section{Acknowledgements}

This work is part of the research project Ref. No. TR-31016, funded by the Ministry of Education, Science and Technological Development, Republic of Serbia.

\section{References}

Abel, S., Ticconi, C.A., Delatorre, C.A. (2002). Phosphate sensing in higher plants. Physiologia Plantarum, 115(1), 1-8.

Abusuwar, A.O., Abdella, A.A. (2004). Effects of seedbed types and phosphorus fertilizer (TSP) on growth and yield of clitoria (Clitoria ternata L.). University of Khartoum Journal of Agricultural Investment, 2, 63-65.

Argaw, A. (2012). Evaluation of Co-inoculation of Bradyrhizobium japonicum and Phosphate Solubilizing Pseudomonas spp. Effect on Soybean (Glycine max L.) in Assossa Area. Journal of Agricultural Science and Technology, 14, 213-224.

Ashley, K.M., Grant, M., Grabov, A. (2006). Plant responses to potassium deficiencies: a role for potassium transport proteins. Journal of Experimental Botany, 57(2), 425-436.

Bahaeldeen, B.M., Fadlalla, A.H., Elhadi, A.E. (2009). Effects of seedbed preparation and potassium application on alfalfa yield. Journal of Science and Technology, 10(3), 1-10.

Brady, N.C., Weil, R.R. (1999). The Nature and Properties of Soils. 9th Edition. Macmillan Publishing Company New York, 750.

Burman, U., Garg, K.B., Kathju, S. (2004). Interactive effects of thiourea and phosphorus on clusterbean under water stress. Biologia Plantarum, 48(1), 61-65.

Cvijović, M., Aćamović, G. (2000). Spektrofotometrijsko određivanje hlorofila. Praktikum iz biohemije, 82.

Dreyer, I., Uozumi, N. (2011). Potassium channels in plant cells. The FEBS Journal, 278, 4293-4303.

Gitari, J.N., Mureithi, J.G. (2003). Effect of phosphorus fertilization on legume nodule formation and biomass production in Mount Kenya Region. East African Agricultural and Forestry Journal, 69(1), 183-187.

Grewal, H.S, Williams, R. (2002). Influence of potassium fertilization on leaf to stem ratio, nodulation, herbage yield, leaf drop and common leaf spot disease of alfalfa. Journal of Plant Nutrition, 25, 781-795.

Haq, M.U., Mallarino A.P. (2005). Response of soybean grain oil and protein concentration to foliar and soil fertilization. Agronomy Journal, 97, 910-918.

Hellsten, A., Huss-Daness, K. (2000). Interaction Effects of Nitrogen and Phosphorus on Nodulation in Red Clover (Trifolium pratense L.). Acta Agriculturae Scandinavica, $50,135-142$.

James, D.W., Tindall, T.A., Hurst, C.J., Hussein, A.N. (1995). Alfalfa cultivar responses to phosphorus and potassium deficiency: Biomass. Journal of Plant Nutrition, 18, 24312445.

Jianbo, S., Lixing, Y., Junling, Z., Haigang, L., Zhaohai, B., Xinping, C., Weifeng, Z., Fusuo, Z. (2011). Phosphorus dynamics: from soil to plant. Plant Physiology, 156, 9971005.

Lester, E.G., Jifon, L.J., Makus, J.D. (2010). Impact of Potassium Nutrition on Food Quality of Fruits and Vegetables: A Condensed and Concise Review of the Literature. Better Crops, 94(1), 18-21.

Lester, G.E., Jifon, L.J., Stewart, M.W. (2007). Foliar potassium improves cantaloupe arketable and nutritional quality. Better Crops, 91 (1), 24-25.

Lewis, D.C., Hawthorne, A.W. (1996). Critical plant and seed concentrations of phosphorus and zinc for predicting response of faba beans (Vicia faba). Australian Journal of Experimental Agriculture, 36(4), 479-484.

Manning, C.A.D. (2009). Mineral sources of potassium for plant nutrition. Agronomy for Sustainable Development, 30(2), 281-294.

Mathur, N., Singh, J., Bohra, S., Bohra, A., Vyas, A. (2006). Effect of soil compaction potassium and cobalt on growth and yield of moth bean. International Journal of Soil Science, 1(3), 269-271.

Muir, P.J., Pitman, D.W., Coombs, F.D. (2001). Seeding Rate, Phosphorus Fertilization, and Location Effects on 'Armadillo' Burr Medic. Agronony Journal, 93: 1269-1275.

Nelson, K.A., Motavalli, P.P., Nathan,M. (2005): Response of notill soybean [Glycine max (L.) Merr] to timing of preplant and foliar potassium applications in a claypan soil. Agronomy Journal, 97, 832-838.

Noack, R.S., McBeath, M.T., McLaughlin, J.M. (2011). Potential for foliar phosphorus fertilisation of dryland cereal crops. Crop and Pasture Science, 61(8), 659-669.

Okalebo, P.L., Woomer, C.O., Othieno, S.O., Gudu, A.O., Nekesa, P.O., Kisinyo, W., Ngetich, D., Lesueur, P., Pypers, B., Vanleuwe, R., Merckx, C., Serem, J., Bashir, D., Mbakaya, B., Ama,r A., Ekwamu, M., Bekunda, J., Ojiem, M., Osundwa, A. (2009). Some current efforts to raise maize and grain legume yields through expanded fertilizer and agricultural lime applications on acid soils of W. Kenya. Proceedings of 25th Conference of Soil Science Society of East Africa. 7-11 December, Moshi, Tanzania.

Oliva, N.R., Steiner, J.J., Young, C.W. (1994). Red Clover Seed Production: II. Plant Water Status on Yield and Yield Components. Crop Science, 34, 184-192.

Parmar, P., Sindhu, S.S. (2013). Potassium Solubilization by Rhizosphere Bacteria: Influence of Nutritional and Environmental Conditions. Journal of Microbiology Research, 3(1), 25-31.

Pettigrew, W.T. (2008). Potassium influences on yield and quality production for maize, wheat, soybean and cotton. Physiologia Plantarum, 133, 670-681.

Raghothama, G.K., Karthikeyan, S.A. (2005). Phosphate acquisition. Plant and Soil, 274, 37-49.

Richardson, E.A. (2009). Regulating the phosphorus nutrition of plants: molecular biology meeting agronomic needs. Plant and Soil, 322, 17-24.

Römheld, V., Kirkby, E.A. (2010). Research on potassium in agriculture: needs and prospects. Plant and Soil, 335, 155-180.

Sawan, M.Z., Fahmy, H.A., Yousef, E.S. (2009). Direct and residual effects of nitrogen fertilization, foliar application of potassium and plant growth retardant on Egyptian cotton growth, seed yield, seed viability and seedling vigor. Acta Ecologica Sinica, 29, 116-123.

Sharpley, A.N., Withers, P.J.A., Abdalla, C.W., Dodd, A.R. (2005). Strategies for the sustainable management of phosphorus. In: Sims J.T., Sharpley A.N. (eds) Phosphorus, agriculture and the environment. American Society for Agronomy, Madison, USA, 1069-1101.

Silberbush, M. (2002). Simulation of ion uptake from the soil. In Waisel Y., Eshel A., Kafkafi U. (eds.) Plant Roots: The Hidden Half. Marcel, Dekker: New York, 651-661.

Singh, S., Gangwar, M.S., Singh H.P., Singh, S. (1999). Nodulation and biomass production in soybean as 
influenced by the application of nutrients. Journal of Potassium Research, 15(14), 127-130.

Singh, S.S. (2000). Soil fertility and Nutrient Management. Kalyani Publishers, Ludhiana, 32-36.

SPSS. Inc. 1995. STATISTICA for Windows (Computer Program Manual). Tulsa. OK.

Tiwari, P.S., Joshi, P.O., Vyas, K.A., Billore, D.S. (2001). Potassium nutrition in yield and quality improvement of soybean. Proceedings of the International Symposium on "Importance of Potassium in Nutrient Management for Sustainable Crop Production in India", New Delhi, India. Available at: https://www.ipipotash.org/uploads/udocs/Potassium\% 20Nutrition\%20in\%20Yield\%20and\%20Quality.pdf, 13.04.2020.

Turner, L., Paphazy, J.M., Haygarth, M.P., McKelvie, D.I. (2002). Inositol phosphates in the environment. Philosophical Transactions of the Royal Society of London. Series B, Biological Sciences, 357, 449-469.

Veneklaas, J.E., Lambers, H., Bragg, J., Finnegan M.P., Lovelock, E.C., Plaxton, C.W., Price, A.C., Scheible, W.R., Shane, W.M., White, J.P., Raven, A.J. (2012). Opportunities for improving phosphorus-use efficiency in crop plants. New Phytologist, 195, 306-320.

White, P.J. (2013). Improving potassium acquisition and utilisation by crop plants. Journal of Plant Nutrition and Soil Science, 176, 305-316.
White, P.J., Greenwood, D.J. (2013). Properties and management of cationic elements for crop growth. In Gregory P.J., Nortcliff S. (eds) Soil Conditions and Plant Growth. Blackwell, Oxford, 160-194.

White, P.J., Karley, A.J. (2010). Potassium. Plant Cell Monographs 17, Cell Biology of Metals and Nutrients. Springer, Berlin, 199-224.

Xiang, D.B., Yong, T.W., Yang, W.Y., Wan, Y., Gong, W.Z., Cui, L., Lei, $T$ (2012). Effect of phosphorus and potassium nutrition on growth and yield of soybean in relay strip intercropping system. Scientific Research and Essays, 7(3), 342-351.

Xu, Y.W., Zou, Y.T., Amjad, M.H., Zeng, J.W., Guan, L.L., Liu, Q., $\mathrm{Wu}, \mathrm{W}$. (2011). Optimization of potassium for proper growth and physiological response of Houttuynia coradata Thunb. Environmental and Experimental Botany, 71, 292-297.

Yoneyama, K., Xie, X., Kim, H., Kisugi, T., Nomura, T., Sekimoto, H., Yokota, T., Yoneyama, K. (2012). How do nitrogen and phosphorus deficiencies affect strigolactone production and exudation. Planta, 235, 1197-1207.

Zörb, C., Senbayram, M., Peiter, E. (2014). Potassium in agriculture - Status and perspectives. Journal of Plant Physiology, 171: 656-669. 